Volume 6 Nomor 1, Februari 2021, halaman 55 - 69.

\title{
Gamifikasi Kemampuan Pemecahan Masalah Matematis: Apa, Mengapa, dan Bagaimana
}

\section{Gamification Of Mathematic Problem Solving Skills: What, Why, and How}

\author{
Riqi Kurniawan', Dhea Andryos Yuntiaji ${ }^{2}$, Dista Anggraeni Safitri ${ }^{3}$, Hamidah \\ Suryani Lukman ${ }^{4}$ \\ ${ }^{1}$ Universitas Muhammadiyah Sukabumi, Sukabumi, rikurniawan019@ummi.ac.id \\ ${ }^{2}$ Universitas Muhammadiyah Sukabumi, Sukabumi, dhea006@ummi.ac.id \\ ${ }^{3}$ Universitas Muhammadiyah Sukabumi, Sukabumi, distasafitri13@ummi.ac.id \\ ${ }^{4}$ Universitas Muhammadiyah Sukabumi, Sukabumi, hamidahsuryani@ummi.ac.id
}

\begin{abstract}
ABSTRAK
Kemampuan pemecahan masalah matematis merupakan salah satu kompetensi penting yang dibutuhkan dalam perkembangan teknologi khususnya pada era revolusi industry 4.0. Kemampuan ini dibutuhkan dalam proses menguasai, mengolah, menyelidiki, menghubungkan, mengerucutkan informasi, mendiagnosa suatu masalah, dan merefleksikan efektivitas suatu strategi di dalam proses menyelesaikan masalah. Penulisan artikel ini bertujuan untuk membantu memberikan informasi terkait peran gamifikasi pada kemampuan pemecahan masalah, pengembangan kemampuan pemecahan masalah matematis, dan penerapan gamifikasi pada kemampuan pemecahan masalah matematis. Metode penelitian yang digunakan terdiri dari beberapa tahap, diantaranya (1) merumuskan masalah, (2) mengumpulkan data, (3) mengevaluasi kelayakan data, (4) menganalisis dan menginterpretasi data yang relevan, dan (5) mengatur serta menyajikan hasil. Adapun data yang dianalisis berasal dari 35 artikel yang terpilih pada jurnal yang telah dipublikasikan. Hasil menunjukan bahwa: 1) penerapan gamifikasi pada kemampuan pemecahan masalah matematis dapat dilakukan melalui pengembangan intrumen tes kemampuan pemecahan masalah matematis berbasis game unity, 2) pengembangan kemampuan pemecahan masalah matematis dapat diakukan melalui model IDEAL Problem Solving, dan 3) proses perancangan instrument tes kemampuan pemecahan masalah matematis berbasis game unity dapat dirancang dengan tahapan pencarian soal-soal tes kemampuan pemecahan masalah matematis yang valid, pembuatan flowchart, perancangan, serta pembuatan aplikasi menggunakan game engine unity.
\end{abstract}

Kata Kunci : Kemampuan Pemecahan Masalah Matematis, IDEAL Problem Solving, Gamifikasi, Unity.

\section{ABSTRACT}

The ability to solve mathematical problems is one of the important competencies needed in technological development, especially in the era of the industrial revolution 4.0. This ability is needed in the process of mastering, processing, investigating, linking, purifying information, diagnosing a problem, and reflecting on the effectiveness of a strategy in the problem-solving process. The writing of this article aims to help provide information regarding the role of gamification in problem-solving abilities, the development of mathematical problem-solving abilities, and the application of gamification to mathematical problem-solving abilities. The research method used consists of several stages, including (1) formulating the problem, (2) collecting data, (3) evaluating the feasibility of the data, (4) analyzing and interpreting relevant data, and (5) organizing and presenting the results. The data analyzed came from 35 articles selected in published journals. The results show that: 1) the application of gamification to mathematical problem-solving abilities can be done through the development of a test instrument 
for mathematical problem-solving abilities based on the unity game, 2) the development of mathematical problem-solving abilities can be done through the IDEAL Problem Solving model, and 3) the design process of the ability test instrument solving mathematical problems based on the unity game can be designed by searching for valid mathematical problem-solving test questions, making flowcharts, designing, and making applications using the unity game engine.

Keyword(s): Mathematical Problem Solving Ability, IDEAL Problem Solving, Gamification, Unity.

How to Cite: Kurniawan, R., Yuntiaji, D. A., Safitri, D. A., Lukman, H. S. Mathline: Jurnal Matematika dan Pendidikan Matematika, Vol. 6 No. 1, 55 - 66.

DOI: https://doi.org/10.31943/mathline.v6i1.200

\section{PENDAHULUAN}

Kemampuan pemecahan masalah merupakan komponen penting dari kurikulum matematika dikarenakan didalamnya terdapat inti dari aktivitas matematika (Nayazik, 2017). Kemampuan pemecahan masalah adalah pendekatan sistematik dan konseptualisasi dalam memahami sebuah masalah yang diberikan, merancang strategi untuk menyelesaikannya, dan mengevaluasi strategi yang diimplementasikan (Albay, 2019). Pemecahan masalah merupakan kemampuan dasar yang perlu dikuasai oleh siswa untuk dapat bersaing secara global karena keterampilan tenaga kerja yang dibutuhkan dalam menghadapi persaingan global adalah memiliki kemampuan memecahkan masalah kompleks secara real time (Laar, et al., 2020). Hal ini didasarkan pada rangkuman kerangka Internasional kompetensi abad 21 yang telah dirumuskan oleh The Assesment and Teaching of $21^{\text {st }}$ Century Skill (ATC21S) bahwa kompetensi yang dibutuhkan pada abad 21 salah satunya adalah proses berpikir yang meliputi kemampuan pemecahan masalah (Haryono, 2017). Oleh karena itu, kemampuan pemecahan masalah matematis di kalangan siswa perlu mendapat perhatian dalam pembelajarannya (Nayazik, 2017).

Charles \& O'Daffer (Haryani, 2011) menyatakan bahwa manfaat kemampuan pemecahan masalah adalah (1) mengembangkan kemampuan berpikir, mengembangkan kemampuan menyeleksi dan menggunakan strategi penyelesaian masalah, (3) mengembangkan sikap dan keyakinan dalam menyelesaikan masalah, (4) mengembangkan kemampuan dalam memonitor/mengevaluasi hasil pemikiran dan hasil kerjanya selama proses pemecahan masalah, (5) mengembangkan kemampuan menggunakan pengetahuan yang saling berelasi, (6) mengembangkan kemampuan menyelesaikan masalah dalam lingkungan yang bersifat kooperatif, dan (7) mengambangkan kemampuan menemukan jawaban yang benar pada soal bervariasi. Kemampuan ini dapat membantu untuk menguasai, mengolah, menyelidiki, 
menghubungkan, mengerucutkan informasi, mendiagnosa suatu masalah, dan merefleksikan efektifitas suatu strategi didalam proses menyelesaikan masalah (Helmon \& Sennen, 2020).

Pada era revolusi industry 4.0 atau disebut juga dengan era digitalisasi, pembelajaran di sekolah sudah mulai berpindah menggunakan perangkat berbasis teknologi. Salah satunya dalam bentuk gamifikasi. Gamifikasi merupakan metode yang mengacu pada proses memperkenalkan, mengubah, dan mengoperasikan sistem pelayanan serta interaksi antara manusia dan komputer yang banyak mengambil inspirasi dari komponen mechanical game dan elemen-elemen game yang membuat proses pembelajaran lebih menyenangkan, karena memasukan unsur game, juga untuk mengikat, memotivasi, dan menyelesaikan masalah siswa dalam pembelajaran (Farida, dkk,. 2018; Farozi, 2016; Jusuf, 2016; Prambayun, dkk., 2016).

Kemampuan pemecahan masalah matematis tidak dapat dilihat secara langsung. Maka untuk mengetahui sejauh mana kemampuan pemecahan masalah siswa, diperlukan sebuah pengujian. Untuk mengetahui tingkat kemampuan pemecahan masalah siswa, guru menggunakan teori tes klasik yang berupa tes tertulis yang berbentuk soal pilihan ganda atau essay. Kekurangan tes klasik saat ini adalah bentuk soal yang kurang variatif sehingga kurang memacu kemampuan berpikir siswa khususnya dalam pemecahan masalah (Edy \& Tandilling, 2012). Padahal Kualitas instrument tes akan mempengaruhi hasil dari pengukuran kemampuan pemecahan masalah. Berdasarkan hasil penelitian menunjukkan bahwa terdapat beberapa faktor yang mempengaruhi kemampuan pemecahan masalah yaitu konteks soal, rumus, penguasaan materi, pemahaman, dll (Kudsiyah, dkk., 2017).

Gamifikasi pada proses pembelajaran dapat membantu meningkatkan motivasi belajar siswa dalam matematika, menghilangkan kejenuhan, mengembangkan pola pikir, serta meningkatkan kreativitas dan kemampuan pemecahan masalah (Rahardja, dkk., 2018). Melalui tampilan dan penyajian permasalah yang tidak biasa, game dapat mengefektifkan waktu pelajaran, fokus dalam pembelajaran, serta dapat diakses dimanapun dan kapan pun. Selain itu, game edukasi juga memiliki kelebihan dibandingkan dengan pembelajaran konvensional, karena cara pembelajarannya disajikan dengan visualisasi bergerak yang menarik (Pujakusuma, dkk., 2018). Sehingga proses pembelajaran yang menggunakan game atau gamifikasi diyakini berhasil meningkatkan aktifitas belajar siswa, motivasi siswa, dan hasil belajar siswa.

Beberapa penelitian menyebutkan bahwa game mempengaruhi kemampuan pemecahan masalah matematika (Ahmadi, 2017). Game dirancang sehingga pengguna 
dapat menentukan taktik dan cara yang tepat untuk mendapatkan reward atau menjadi pemenang dari permainan tertentu, ini merupakan salah satu implementasi dari indikator pemecahan masalah yaitu mengidentifikasi masalah, menentukan tujuan, dan menemukan strategi yang mungkin (Ahmadi, 2017; Muthianisa \& Anggarani, 2019)

Sebagai salah satu upaya pembaruan dalam mengukur kemampuan pemecahan masalah matematis siswa, dengan tujuan agar meningkatkan minat siswa dalam memecahkan masalah matematika, perlu adanya kolaborasi dan integrasi antara pembuatan instrument dan game yang sangat menarik digunakan dalam pembelajaran. Hal ini sejalan dengan beberapa hasil penelitian yang mengungkapkan bahwa faktor-faktor yang mempengaruhi kemampuan pemecahan masalah diantaranya adalah konteks soal dan apresiasi matematika (Dwianjani \& Candiasa, 2018; Kudsiyah, dkk., 2017).

Berdasarkan latar belakang tersebut, artikel ini bertujuan untuk membantu memberikan informasi terkait peran gamifikasi pada kemampuan pemecahan masalah, pengembangan kemampuan pemecahan masalah matematis, dan penerapan gamifikasi pada kemampuan pemecahan masalah matematis.

\section{METODE PENELITIAN}

Kegiatan yang dilakukan dalam penyusunan artikel ini terdiri dari beberapa tahapan, yaitu (1) merumuskan masalah, (2) mengumpulkan data, (3) mengevaluasi kelayakan data, (4) menganalisis dan menginterpretasi data yang relevan, dan (5) mengatur serta menyajikan hasil yang kemudian hasil yang diperoleh dibandingkan dengan isu-isu saat ini (Suhartono, 2017).

Data dikumpulkan melalui pencarian literature baik nasional ataupun internasional pada database Science Direct, ERIC, Google Scholar, z-library dan IEEE dari tahun 2015. Kata kunci yang digunakan adalah unity game for mathematics (5913), gamifikasi/gamification for mathematics (3188), IDEAL (Identify problem, Define goal, Explore possible strategies, Anticipate outcomes and act, Look back and learn) problem solving models for mathematics (10751), mathematical problem solving (7357) dan math test instrument development (210). Total artikel yang ditemukan sebanyak 27.419 artikel. Selanjutnya dilakukan skrining berdasarkan judul, abstrak, dan tahun terbit untuk mencari artikel yang relevan. Berdasarkan hasil skrining tersebut diperoleh 35 artikel yang relevan dengan penelitian ini. Berdasarkan jumlahnya, terdapat 6 artikel membahas tentang unity game for mathematics, 8 artikel tentang gamifikasi/gamification for mathematics, 12 artikel tentang mathematical problem solving dan IDEAL problem solving for 
mathematics, serta 9 artikel tentang math test instrument development. Secara rinci ke 35 artikel tersebut disajikan pada table 1.

\section{Tabel 1. Persentase Sampel Penelitian}

\begin{tabular}{ll}
\hline Fokus & \multicolumn{1}{c}{ Sumber } \\
\hline Gamifikasi & Farida, dkk., 2018; Farozi, 2016; Inawati \& Puspasari, \\
& 2021; Pujakusuma, dkk., 2018; Wardana \& Sagoro, \\
& 2019; Rahardja, dkk., 2018; Suarmini, 2019; \\
& Ramansyah, 2016; \\
& Adiqro, 2018; Susanto, dkk., 2016; Ramansyah, 2016; \\
Unity & Dewi, dkk. 2019.; Farozi, 2016; \\
& Adiqro, 2018; Susanto, dkk., 2016; Ramansyah, 2016; \\
IDEAL Peoblem & Dewi, dkk. 2019;; Farozi, 2016; \\
Solving & Hidayat, dkk., 2017; Lestari, dkk., 2019; Sinaga, 2016; \\
Instrumen Tes & Dewi, dkk., 2015; Patil \& Alvares, 2015; Pujakusuma, \\
& dkk., 2018; Wulandari, 2016; Muadin, 2011; \\
& Mawarni, 2018; \\
\hline
\end{tabular}

\section{HASIL DAN PEMBAHASAN}

\section{Peran Gamifikasi pada Kemampuan Pemecahan Masalah}

Pada pembelajaran matematika gamifikasi didefinisikan sebagai sebuah pendekatan pembelajaran dimana didalamnya menggunakan komponen-komponen dari game, video game atau mekanisme game yang bertujuan untuk memberikan motivasi, menumbuhkan perasaan nyaman dan engagement (keinginan berpartisipasi baik secara tindakan, emosi dan kognitif) pada proses pembelajaran, dan menjadikan pembelajaran agar lebih menarik (Solviana M. D., 2020; Suarmini M., 2019; Jusuf H., 2016). Glover berpendapat bahwa gamifikasi selain mampu memotivasi siswa juga mampu menjamin siswa mengikuti pembelajaran secara lengkap (Jusuf H., 2016). Terdapat Unsur-unsur penting dalam penerapan gamifikasi pada pembelajaran khususnya matematika yaitu terdiri dari peraturan, kejelasan tujuan dan hasil, pemecahan masalah, story, pemain, save environment, tantangan \& rasa penguasaaan, dan feedback \& reward (Suarmini M., 2019). Karakteristik dari desain aktivitas menggunakan gamifikasi yaitu, memenuhi tujuan dan hasil pembelajaran yang jelas, dapat mengidentifikasi keterampilan dasar yang diperlukan siswa, terdapat tantangan dari permainan, memiliki skema warna yang menarik, tata letak yang rapi, kemudian isntruksi yang ringkas dan jelas, aturan main yang sederhana dan mudah untuk dipahami, konten yang akurat dan relevan dengan subjek yang diangkat, feedback, dll (Moncada, S. et. al., 2014).

Terdapat beberapa bentuk penerapan gamifikasi dalam pembelajaran. kemudian Aplikasi yang dapat digunakan untuk membuat instrument tes kemampuan pemecahan 
matematis siswa adalah Game Unity. Unity merupakan game engine yang memberikan keuntungan yang besar dibandingkan game engine lainnya, hal ini disebabkan karena unity memberikan kapabilitas drag-and-drop pada alur kerja visualnya serta mendukung pemograman Bahasa $\mathrm{C \#}$, pengembangan grafis 3D dan 2D, menyediakan seperangkat peralatan yang selalu mendapat pembaharuan (Nasution, dkk., 2019).

Game unity merupakan kolaborasi game yang menggunakan Unity sebagai game engine dan instrument tes yang sangat memungkinkan siswa mengembangkan kemampuan pemecahan masalah. Aplikasi Unity memiliki fitur yang sangat baik untuk mengembangkan kemampuan mengidentifikasi masalah, mencari strategi yang mungkin, dan melaksanakan strategi. Karena sebelum siswa menjawab persoalan, siswa harus mengetahui dulu persoalan apa yang harus mereka carikan solusi. Kemudian mencoba untuk mencari dan menggunakan alternatif strategi untuk dapat menaikkan level. Contohnya adalah pada instrumen tes kemampuan pemecahan masalah berbasis game unity yang dikembangkan oleh Kurniawan R., dkk., (2021) dimana pada panel visualisasi masalah yang dihadirkan berupa ilustrasi masalah dengan gambar, siswa diarahkan untuk dapat mengisi jawaban dari permasalah tersebut beradasarkan model pemecahan masalah IDEAL yaitu dengan menjawab pertanyaan berdasarkan dari unsur-unsur IDEAL problem solving seperti Identify the problem, Define the problem, Explore solution, Act on the strategy, Look back, and Evaluate the effect dapat dilihat pada gambar 1.

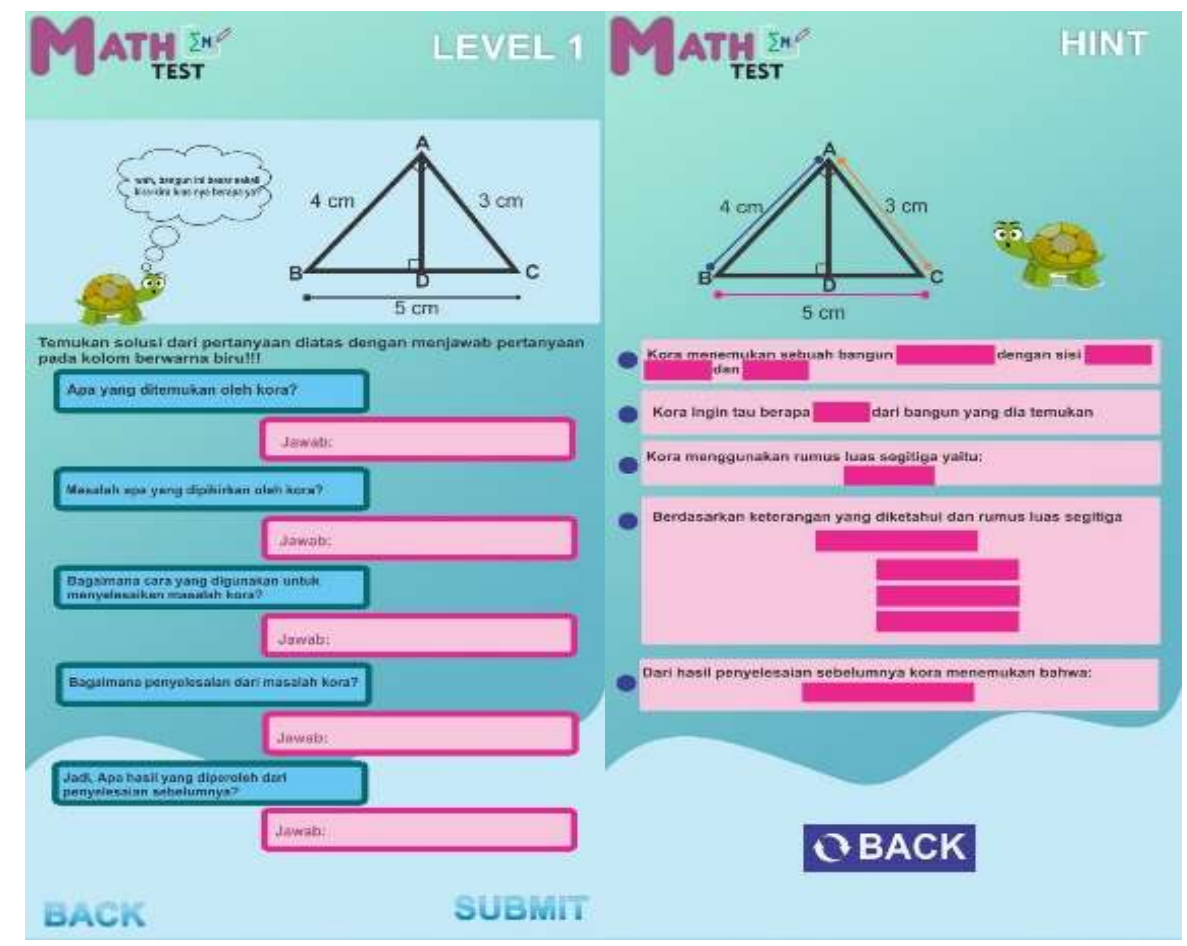

Gambar 1. Contoh Visualisasi masalah dalam Instrumen Tes Kemampuan Pemecahan Masalah Matematis Berbasis Game Unity 


\section{Pengembangan Kemampuan Pemecahan Masalah Matematis Melalui Model Ideal Problem Solving}

Terdapat beberapa model yang dapat digunakan untuk mengembangkan kemampuan pemecahan masalah yaitu model kemampuan pemecahan masalah yang dipelopori oleh George Polya, model Taksonomi SOLO yang dipelopori oleh Bigg \& Collis, model Newman yang dipelopori oleh Anne Newman, dan model IDEAL Problem solving dipelopori oleh Bransford dan Stein (Arifin, 2019; Halimah, dkk., 2020; Nabiila, 2016). Perbedaan mendasar model tersebut diantaranya, proses pemecahan masalah Polya disebut heuristic dimana tidak menjamin solusi yang tepat, tetapi hanya memandu dalam menemukan solusi dan tidak menuntuk langkah yang sistematik (Arifin, 2019). Pada model taksonomi SOLO, proses pemecahan masalah bersifat hirarki sehingga digunakan sebagai media menentukan kualitas jawaban siswa terhadap suatu masalah matematika (Halimah, dkk., 2020). Sedangkan model pemecahan masalah IDEAL problem solving didesain untuk membantu mengidentifikasi dan memahami bagian-bagian yang berbeda dari penyelesaian masalah, masing-masing huruf melambangkan komponen penting dalam proses penyelesaian masalah (Yanti \& Syazali, 2016).

IDEAL problem solving adalah sebuah model yang dijadikan sebuah strategi untuk mengembangkan kemampuan berpikir dan memecahkan masalah yang memiliki makna yaitu mengidentifikasi masalah, menentukan tujuan, mencari strategi yang mungkin, melaksanakan strategi yang ditentukan, melihat kembali dan mengevaluasi dampak dari strategi yang ditentukan (Himmatul, 2016). Langkah-langkah dalam model IDEAL Problem solving yang diperoleh dari beberapa literature terdiri dari lima tahap pembelajaran, yaitu identify the problem, define the problem, explore solution, act on the strategy, look back, and evaluate the effect (Eksan, dkk., 2017; F. Indriyani, dkk., 2018; Maharani, dkk., 2013). Keterlibatan model IDEAL Problem solving dalam aktivitas kognitif dapat dilihat dalam tiga hal yaitu: (1) penyajian masalah yang meliputi aktivitas mengingat konteks pengetahuan yang sesuai dan melakukan identifikasi tujuan serta kondisi awal yang relevan untuk masalah yang dihadapi, (2) pencarian pemecahan meliputi aktivitas pengahalusan (penetapan) tujuandan pengembangan rencana tindakan untuk mencapai tujuan, (3) penerapan solusi meliputi tindakan pelaksanaan rencana tindakan dan mengevaluasi hasilnya (Eksan, dkk., 2017).

Berdasarkan beberapa hasil penelitian, tahapan-tahapan pada model pembelajaran IDEAL Problem Solving dapat menggali kreativitas siswa dalam menyelesaikan masalah, sehingga siswa dapat mempunyai keterampilan dalam memecahkan masalah yang 
dihadapi. Selain itu tahapan IDEAL problem solving juga dapat melatih siswa untuk mengemukakan ide yang dimilikinya, berpikir kritis untuk memecahkan masalah, berpikir sistematis dan logis sesuai data yang tersedia, melatih siswa untuk saling berinteraksi dengan teman maupun guru. (Indriyani \& Masriyah, 2016), meningkatkan atifitas siswa, juga berpengaruh terhadap pengelolaan pembelajaran guru (Nayazik \& Wahyuni, 2017; Amalia, dkk., 2019; Elfiani, 2017; Indriyani \& Masriyah, 2016). Oleh karena itu, IDEAL problem solving diyakini dapat membantu untuk menyelesaikan masalah di dalam pembelajaran (Nabiila, 2016; Nayazik \& Wahyuni, 2017).

\section{Penerapan Gamifikasi pada Kemampuan Pemecahan Masalah Matematis}

Pengembangan perangkat pembelajaran matematika yang berbasis teknologi informasi sudah banyak bermunculan, salah satunya melalui bentuk gamifikasi, termasuk produk pemerintah terkait Ujian Nasional Berbasis Komputer (UNBK) yang beberapa tahun terakhir selalu digunakan. Begitupun dengan instrument pengukur hasil belajar siswa atau kemampuan berpikir siswa, saat ini gamifikasi sudah banyak digunakan salah satunya menggunakan aplikasi math riddles. Math riddles merupakan aplikasi game teka-teki untuk melatih kemampuan berpikir siswa khusunya dalam kemampuan analisis yang dikembangkan oleh seorang game developer bernama black games menggunakan Unity game engine sebagai alat bantu untuk membuat game tersebut, dapat dilihat pada gambar berikut ini.

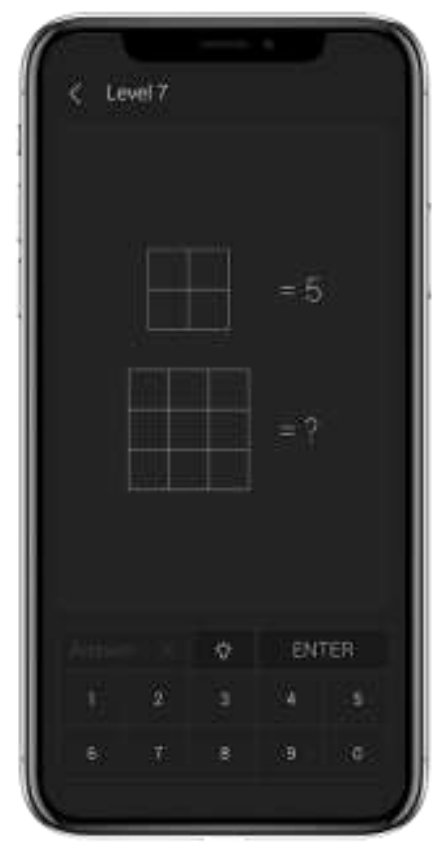

Gambar 2. Contoh Visualisasi masalah pada Math Riddles 
Pada math riddles ini user atau siswa diarahkan untuk menyelesaikan permasalahan antara angka didalam gambar geometris dan mencari angka yang hilang di bagian akhir, disetiap level dari game ini memiliki level yang berbeda dan hanya membutuhkan kemampuan berpikir analitis yang kuat untuk menemukan pola dari angka-angka yang diberikan (Games B., 2018). Sehingga dapat dikatakan aplikasi ini masih hanya sebatas menjawab secara singkat soal teka-teki matematika saja. Sedangkan pengembangan instrumen tes yang spesifik dalam mengukur kemampuan pemecahan masalah matematis siswa yang berbasis teknologi informasi masih sangat jarang dikembangkan. Salah satu kendalanya disebabkan oleh pemahaman guru terkait analisis soal dengan pendekatan modern masih kurang (Hasnah, 2017).

Padahal, untuk mengetahui bagaimana kemampuan pemecahan masalah siswa diperlukan sebuah pengujian atau pengukuran. Salah satu alat untuk mengukur atau menguji kemampuan siswa adalah instrumen tes atau soal (Sa'idah, dkk., 2018). Kualitas instrument tes akan mempengaruhi hasil dari pengukuran kemampuan pemecahan masalah.

Pada umumnya untuk mengetahui tingkat kemampuan pemecahan masalah siswa, guru menggunakan teori tes klasik yang berupa tes tertulis yang berbentuk soal pilihan ganda atau essay. Namun, terdapat beberapa kekurangan dari penggunaan instrumen tes klasik yang saat ini digunakan salah satunya yaitu bentuk soal yang kurang variatif sehingga kurang memacu kemampuan berpikir siswa khususnya dalam pemecahan masalah (Edy \& Tandilling, dkk., 2012).

Beberapa hasil penelitian pengembangan menggunakan unity yang telah berhasil diujicoba mencapai $70 \%$. Produk yang dikembangkan berhasil membantu memahami materi, meningkatkan minat belajar siswa dan menghibur. Pengembangan tersebut telah memiliki nilai efektifitas, efisiensi, dan daya tarik untuk digunakan (Adiqro, 2018; Ramansyah, 2016; Susanto, dkk., 2016).

Proses penyusunan instrumen tes berbasis game unity dapat dimulai dengan proses pencarian sumber-sumber soal kemampuan pemecahan masalah sesuai dengan indikator kemampuan pemecahan masalah yang mengacu pada teori IDEAL problem-solving yang memenuhi kriteria valid dan reliabel dari karya ilmiah atau artikel yang telah dipublikasikan. Kemudian dilakukan tahapan desain yang dimulai dengan pembuatan flowchart atau diagram alir menu awal dan menu-menu lainnya. Langkah ketiga adalah pembuatan desain/tampilan game yang bertujuan untuk membantu membuat aplikasi sehingga sesuai dengan gambaran awal yang diharapkan (Dewi, dkk., 2015; Patil \& Alvares, 2015; Pujakusuma, dkk., 2018). Setelah proses pembuatan desain, dibutlah 
prototype menggunakan aplikasi unity engine sebagai alat untuk merakit aplikasi. Selanjutnya mengkoneksikan menu-menu tersebut ke masing-masing fungsi yang telah ditentukan dengan cara memasukkan script atau perintah dalam bentuk algoritma kedalam menu tersebut. Setelah semua menu tersebut terkoneksi, selanjutnya dibuat menu-menu lainnya sesuai dengan desain tampilan aplikasi yang sudah dibuat sebelumnya. Setelah semua menu selesai dibuat aplikasi kemudian dibuild dalam bentuk android.

Berdasarkan hasil review literatur diperoleh bahwa manfaat dari pengembangan instrumen tes kemampuan pemecahan masalah berbasis game unity yaitu dapat meningkatkan kemampuan berpikir dan keterampilan proses pemecahan masalah juga siswa dapat menggali kreativitasnya dan dapat mengemukakan ide yang dimiliki dalam menyelesaikan masalah yang dihadapi. Selain itu, pengembangan instrumen tes berbasis game unity dapat menarik perhatian siswa dalam proses pembelajaran, menjadi lebih mudah dalam memahami materi, mengenal teknologi, lebih banyak melakukan kegiatan, meningkatkan motivasi belajar dan hasil belajar karena menampilkan fitur yang menghibur dan menyenangkan bagi siswa SMP. Pengembangan instrumen tes yang valid selain membuat siswa menjadi lebih tertarik dalam pembelajaran juga pengukuran mengenai kemampuan pemecahan masalah dapat menghasilkan pengukuran yang tepat dan benar (Darmawan, dkk., 2020; Dewi, dkk., 2015; Kurniawan, dkk., 2018; Rahardja, dkk., 2018; Ramansyah, 2016; Suarmini, 2020; Wardana \& Sagoro, 2019).

\section{KESIMPULAN}

Berdasarkan hasil dan pembahasan di atas maka dapat disimpulkan bahwa: (1) Peran gamifikasi pada kemampuan pemecahan masalah salah satunya melalui kolaborasi game dengan instrument tes melalui game unity yang sangat memungkinkan siswa mengembangkan kemampuan pemecahan masalah melalui proses mengembangkan kemampuan mengidentifikasi masalah, mencari strategi yang mungkin, dan melaksanakan strategi. (2) Mengembangkan kemampuan pemecahan masalah dapat dilakukan melalui model IDEAL Problem Solving karena tahapannya mampu menggali kreativitas siswa dalam menyelesaikan masalah. Adapun langkah-langkah dalam model IDEAL problem solving terdiri dari lima tahap pembelajaran, yaitu identify the problem (identifikasi masalah), define the problem (mendefinisikan masalah), explore solution (mencari solusi), act on the strategy (melaksanakan strategi), look back, and evaluate the effect (mengkaji kembali dan mengevaluasi pengaruh). (3) Penerapan gamifikasi pada kemampuan pemecahan masalah matematis dapat dilakukan melalui pengembangan intrumen test 
kemampuan pemecahan masalah matematis berbasis game unity yang dapat meningkatkan kemampuan berpikir dan keterampilan proses pemecahan masalah. Siswa juga mampu menggali kreativitas dan mengemukakan ide yang dimilikinya dalam menyelesaikan masalah yang dihadapi. Adapun proses perancangan instrument tes kemampuan pemecahan masalah matematis berbasis game unity dapat dimulai dengan pencarian soalsoal tes yang valid, pembuatn flowchart dan desain, serta pembuatan aplikasi menggunakan game engine unity.

Kekurangan pada penelitian ini yaitu penelitian ini masih berupa kajian literature atau studi pustaka yang bersumber dari artikel-artikel dari jurnal nasional maupun internasional yang sudah di terbitkan. Secara spesifik pengembangan intrumen test kemampuan pemecahan masalah matematis khususnya berbasis game unity yang menggunakan pendekatan gamifikasi dalam penyusunan instrumen belum dapat dilikakukan dikarenakan situasi dan kondisi yang belum memungkinkan untuk dilakukan pengembangan dan implementasi instrumen.

Diharapkan terdapat penelitian yang tuntas dan spesifik mengembangkan intrumen test kemampuan pemecahan masalah matematis berbasis game unity yang didalam nya terdapat elemen-elemen pendekatan gamifikasi yang menggunakan metode research and development untuk dapat secara langsung mengetahui efektifitas, efisisensi, dan validitas dari pengembangan intrumen test kemampuan pemecahan masalah matematis berbasis game unity dengan menggunakan pendekatan gamifikasi ini, sehingga dapat menjadi alat yang dapat digunakan pada pembelajaran matematika di sekolah.

\section{UCAPAN TERIMAKASIH}

Penelitian ini dibiayai oleh Direktorat Pembelajaran dan Kemahasiswaan Direktorat Jenderal Pendidikan Tinggi Kementerian Pendidikan Pendidikan dan Kebudayaan melalui Program Kreativitas Mahasiswa pada Skim Penelitian Sosial Humaniora (PKM-PSH) tahun 2020. Oleh karena itu, kami mengucapkan banyak terimakasih yang tak terhingga kepada Dosen Program Studi Pendidikan Matematika Fakultas Keguran dan Ilmu Pendidikan Universitas Muhammadiyah Sukabumi, Fakultas Keguruan dan Ilmu Pendidikan Universitas Muhammadiyah Sukabumi, Tim Kemahasiswaan Universitas Muhammadiyah Sukabumi, dan TIM PKM Universitas Muhammadiyah Sukabumi sehingga penelitian ini berjalan lancar dan tepat waktu. 


\section{DAFTAR PUSTAKA}

Adiqro, A. F. (2018). Aplikasi Pembelajaran Menulis Permulaan Berbasis Android Menggunakan Unity 2D. Journal of Information and Technology, 6(1), 53-62.

Ahmadi, A. (2017). Pengaruh Kebiasaan Bermain Game Dan Konsep Diri Terhadap Kemampuan Pemecahan Masalah Matematika di SMP NU 1 Hasyim Asy'ari Tarub. Cakrawala: Jurnal Pendidikan, 11(2), 9-11.

Albay, E. M. (2019). Social Sciences \& Humanities Open Analyzing the effects of the problem solving approach to the performance and attitude of fi rst year university students. Social Sciences \& Humanities Open, 1(1), 100006.

Amalia, N., Darma, Y., \& Wahyudi, W. (2019). Pengembangan Pop Up Book Smp Berbasis Ideal Problem Solving Untuk Meningkatkan Kemampuan Pemecahan Masalah Matematis. Prosiding Seminar Nasional Pendidikan MiIPA Dan Teknologi (SNPMT II), 1(1), 389-398.

Arifin, Z. (2019). Perbandingan Prosedur Polya dan Newman Pada pemecahan masalah ( Compatison of Polya and newman Procedures On Problem Solving of Mathematics ). THEOREMS, 3(2), 11-12.

Darmawan, A., Asa, B. N., Kurniawan, F., \& Nukhba, R. (2020). Pengembangan Instrumen Tes Pemecahan Masalah Bagi Mahasiswa Jurusan Fisika Pada Materi Dinamika Partikel. 6(1), 55-64.

Dewi, A. R., Isnanto R., Martono K. T. (2015). Aplikasi Multimedia Sebagai Media Pembelajaran Ilmu Pengetahuan Sosial Materi Budaya Di Indonesia Menggunakan Unity Engine Untuk Sekolah Dasar. Jurnal Teknologi Dan Sistem Komputer, 3(4), 471-480.

Komarudin, Ona S., Tinaliah, Dewi. (2019). Rancang Bangun Aplikasi Pembelajaran Berhitung dengan Teknik Sempoa Berbasis Unity 3D. IJCSS, STMIKGI MSD, 1-13.

Dwianjani, N. K. V., \& Candiasa, I. M. (2018). Identifikasi Faktor-Faktor yang Mempengaruhi Kemampuan Pemecahan Masalah Matematika. NUMERICAL: Jurnal Matematika Dan Pendidikan Matematika, 2(2), 153-166.

Edy, \& Tandilling. (2012). Regulated Learning Siswa dalam pembelajaran matematik di sekolah menengah atas. Jurnal Penelitian Pendidikan, 13(1), 24-31.

Eksan, M. B. S., Wiguna, F. A., \& Wahyu, N. (2017). Penerapan Creative Problem Solving (CPS) Dan Ideal Problem Solving Berbasis Pengalaman Nyata (Experiencing) Ditinjau Dari Motivasi Belajar Mahasiswa. KALAM CENDEKIA, 5(1), 1-9.

Elfiani, F. (2017). Upaya Meningkatkan Kemampuan Berpikir Kreatif Siswa Kelas VII F MT S MA ' ARIF NU 1 Wangon Melalui Pembelajaran Ideal Problem Solving. AlphaMath Journal of Mathematics Education, 3(2), 27-35.

Farida, F. Khoirunnisa, Putra, R.W.Y. (2018). Pengembangan Bahan Ajar Gamifikasi pada Materi Bangun Ruang Sisi Lengkung. JPPM, 11(2), 193-204.

Farozi, M. (2016). Rancang Bangun Website Gamifikasi Sebagai Hasil Belajar Mahasiswa Studi Kasus: Amik Lembah Dempo Pagar Alam. Seminar Nasional Teknologi Informasi Dan Multimedia 2016, 4(1), 6-7.

Games, B. (2018). Challage Yourself with Math Riddles and Puzzels. 1-5. Http://Blackgames.Co/.

Halimah, Untu Z., \& Suriaty. (2020). Analisis Kemampuan Pemecahan Masalah Matematika Berdasarkan Taksonomi Structure of Observed Learning Outcomes (SOLO). PRIMATIKA, 9(1), 1-10.

Haryani, D. (2011). Pembelajaran Matematika Dengan Pemecahan Masalah Untuk Menumbuhkembangkan Kemampuan Berpikir Kritis Siswa. Prosiding Seminar Nasional Penelitian, Pendidikan Dan Penerapan MIPA, 1980, 121-126.

Haryono. (2017). Teknologi pendidikan dan pembelajaran abad 21. Seminar Nasional 
Teknologi Pendidikan, 425-436.

Hasnah. (2017). Analisis Kualitas Soal Matematika Ujian Sekolah Kelas XII IPA SMA Negeri di Watansoppeng Berdasarkan Teori Respon Butir. PEP Educational Assessment, 1(1), 27-33.

Helmon, A., \& Sennen, E. (2020). Pembelajaran matematika Melalui Pemecahan Masalah : Urgensi Dan Penerapannya. Jurnal Inovasi Pendidikan Dasar, 4(1), 51-56.

Hidayat, S.R., Setyadin A.H., Hermawan, Karniawati I., Suhendi E., Siahaan P., \& Samsudin A., (2017). Pengembangan Instrumen Tes Keterampilan Pemecahan Masalah Pada Materi Getaran, Gelombang, dan Bunyi. Jurnal Penelitian \& Pengembangan Pendidikan Fisika, 3(2), 157-166.

Himmatul, U. (2016). Profil Kemampuan Pemecahan Masalah Siswa Bermotivasi Belajar Tinggi Berdasarkan Ideal Problem Solving. Konseling Gusjigang, 2(1), 90-96.

Inawati A., \& Puspasari D. (2021). Pengembangan Media Pembelajaran Interaktif Game Ular Tangga Berbasis Game Unity 3D Pada Mata Pelajaran Kearsipan Kelas X OTKP di SMKN 4 Surabaya. Jurnal Pendidikan Administrasi Perkantoran (JPAP), 9(1), 96108.

Indriyani, F., Nurcahyono, N. A., \& Nur, A. (2018). Analisis Kemampuan Pemecahan Masalah Siswa Berdasarkan Langkah Ideal Problrm Solving. PYTHAGORAS, 7(2), $56-67$.

Indriyani, R. W., \& Masriyah. (2016). Penerapan Model Pembelajaran Ideal Problem Solving Dalam Menyelesaikan Masalah Matematika Pada Materi Keliling Dan Luas Persegipanjang Dan Persegi Bagi Siswa Kelas VII SMP. MATHEdunesa Jurnal Ilmiah Pendidikan Matematika, 2(5).

Jusuf, H. (2016). Penggunaan Gamifikasi dalam Proses Pembelajaran. Jurnal TICOM, 5(1), 1-6. https://media.neliti.com/media/publications/92772-ID-penggunaangamifikasi-dalam-proses-pembe.pdf

Kudsiyah, S. M., Novarina, E., \& Lukman, H. suryani. (2017). Faktor-Faktor Yang Mempengaruhi Kemampuan Pemecahan Masalah Matematika Kelas X Di Sma Negeri 2 Kota Sukabumi. Education: Prodi Pendidikan Matematika FKIP Universitas Muhammadiyah Sukabumi, 110-117.

Kurniawan, B. R., Reyza, M., \& Taqwa, A. (2018). Pengembangan Instrumen Tes Kemampuan Pemecahan Masalah Fisika pada Materi Listrik Dinamis. Jurnal Pendidikan: Teori, Penelitian, Dan Pengembangan, 3(11), 1451-1457.

Kurniawan, R., Lukman, H. S., \& Nurcahyono, N. A. (2021). Desain Instrmen Tes Kemampuan Pemecahan Masalah Matematid Berbasis Game Unity. Range: Jurnal Pendidikan Matematika Universitas Timor, 3(1).

Laar, E. Van, Deursen, A. J. A. M. Van, Dijk, J. A. G. M. Van, \& Haan, J. De. (2020). Poetics Measuring the levels of 21st-century digital skills among professionals working within the creative industries: A performance-based approach. Poetics, 81(April 2019), 101434.

Lestari, P. E., Purwanto, A., \& Sakti, I. (2019). Pengembangan instrumen tes keterampilan pemecahan masalah pada konsep usaha dan energi di sma. Jurnal Kumparan Fisika, 2(3), 161-168.

Maharani, F. W., Bektiarso, S., \& Prihandono, T. (2013). Kemampuan Siswa Sma Dalam Menyelesaikan Soal Un Fisika Berdasarkan Tahapan Model Ideal Pada Materi Listrik Statis. Jurnal Pembelajaran Fisika, 7, 154-161.

Mawarni, A. N. A. N. S. (2018). Keefektivan Model Pembelajaran Arias Berbasis Budaya Terhadap Kemampuan Pemecahan Masalah Siswa. Skripsi. UMMI Sukabumi: Tidak diterbitkan.

Moncada, Susan M; Moncada, T. P. (2014). Gamification of Learning in Accounting 
Education. Journal of Higher Education Teory and Practice, 14(3), 9-19.

Muadin, M. (2011). Efektivitas model pembelajaran matematika dengan pendekatan penemuan terbimbing disertai metode.

Muthianisa, L., \& Anggarani, P. F. (2019). Permainan matematika berbasis teknologi dalam era kelas digital. Prosiding Sendika, 5(1), 524-529.

Nabiila, Z. P. W. (2016). Penerapan Model Pembelajaran Kooperatif dengan Strategi Pemecahan Masalah IDEAL pada Materi Luas Permukaan Kubus dan Balok di Kelas VIII. MathEdunesa, 2(5), 199-126.

Nasution, S., Nasution, A. H., \& Hakim, A. L. (2019). Pembuatan Plugin Tile-Based Game Pada Unity 3D. It Journal Research and Development, 4(1), 46-60.

Nayazik, A. (2017). Pembentukan Keterampilan Pemecahan Masalah Melalui Model IDEAL Problem Solving Dengan Teori Pemrosesan Informasi. Kreano, Jurnal Matematika Kreatif-Inovatif, 8(2), 182-190.

Nayazik, A., \& Wahyuni, A. (2017). Peningkatan Kemampuan Komunikasi Matematis Mahasiswa melalui Model Ideal Problem Solving dalam Aspek Gramatika dan Sosiolinguistik. Jurnal Didaktik Matematika, 2(2).

Patil, P. P., \& Alvares, R. (2015). Cross-platform Application Development using Unity Game Engine. International Journal of Advance Research in Computer Science and Management Studies, 3(4), 1-9.

Prambayun, A., Suyanto, M., \& Sunyoto, A. (2016). Model gamifikasi untuk sistem manajemen pembelajaran. Seminar Nasional Teknologi Informasi Dan Multimedia 2016, 4(1), 6-7.

Pujakusuma, G. A., Haryanto, D., Wirandhanu, M. I., \& Pramudya, S. A. (2018). Game Incredible Math Berbasis Android sebagai Media Pembelajaran Virtual Reality. Prosiding Seminar Nasional Matematika Dan Pendidikan Matematika (SNMPM II), 2(1), 331-345.

Rahardja, U., Aini, Q., Ariessanti, H. D., \& Khoirunisa, A. (2018). Pengaruh gamifikasi pada idu (ilearning education) dalam meningkatkan motivasi belajar mahasiswa. NJCA, 3(2), 120-124.

Ramansyah, W. (2016). Pengembangan Game Edukasi "Aksara Jawa" Berbasis Unity untuk Siswa Kelas 3 SDN Mulyoarjo 3 Lawang. Jurnal Ilmiah Edutic: Jurnal Pendidikan Dan Informatika, 2(3), 31-42.

Sa'idah, N., Yulistianti, H. D., \& Megawati, E. (2018). Analisis Instrumen Tes Higher Order Thinking Matematika Smp. Jurnal Pendidikan Matematika, 13(1), 41-54.

Solviana, M. D. (2020). Pemanfaatan Teknologi Pendidikan Di Masa Pandemi Covid-19: Penggunaan Fitur Gamifikasi Daring Di Universitas Muhammadiyah Pringsewu Lampung. Al-Jahiz: Journal of Biology Education Research, 1(1), 1-14.

Suarmini, M. (2019). Metode Gamifikasi Berbasis Tri Hita Karana sebagai Alternatif Pembelajaran Abad 21. Maha Widya Nhuwana: Jurnal Pendidikan, Agama Dan Budaya, 2(2), 42-47.

Suarmini, M. (2020). Metode Gamifikasi Berbasis Tri Hita Karana Sebagai Alternatif Pembelajaran Abad 21. Maha Widya Bhuwana: Jurnal Pendidikan, Agama Dan Budaya, 2(2), 42-47.

Suhartono, E. (2017). Systematic Literatur Review ( SLR ): Metode , Manfaat, Dan Tantangan Learning Analytics Dengan Metode Data Mining di Dunia Pendidikan Tinggi. Jurnal Ilmiah INFOKAM, 13(1), 73-86.

Susanto, D., Basuki, A., \& Hakim, D. R. (2016). Mobile Augmented Reality Untuk Pembelajaran IPA Kelas 7 Kurikulum 2013. Prosiding SENTIA 2016, 8(2011), 69-74.

Wardana, S., \& Sagoro, E. M. (2019). Implementasi Gamifikasi Berbantu Media Kahoot untuk Meningktkan Aktivitas Belajar, Motivasi Belajar, dan Hasil Belajar Jurnal 
Penyesuaian Siswa Kelas X Akuntansi 3 di SMK Koperasi Yogyakarta Tahun Ajaran 2018/2019. Jurnal Pendidikan Akuntansi Indonesia, XVII, No 2, 46-57.

Wulandari, Y. (2016). Penerapan Model Pembelajaran Berbasis Masalah Terhadap kemampuan Pemecahan Masalah Matematika Siswa Di SMP Negeri 1 Padang.

Yanti, A. P., \& Syazali, M. (2016). Analisis Proses Berpikir Siswa dalam Memecahkan Masalah Matematika Berdasarkan Langkah-Langkah Bransford dan Stein Ditinjau dari Adversity Quotient. Al-Jabar: Jurnal Pendidikan Matematika, 7(1), 63-74. 